\title{
Leituras semióticas de Pinóquio
}

\author{
Rafael Giardini Lenzi
}

FABBRI, P.; PEZZINI, I (ORG.).

Pinocchio:

nuove avventure tra segni e linguaggi.

Milão, Mimesis Insegne, 242 p., 2012.

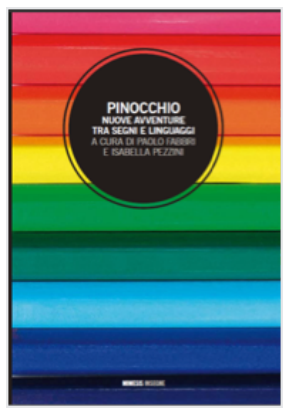

Resumo: Esta resenha faz breve exposição do conteúdo de Pinocchio: nuove avventure tra segni e linguaggi, organizado por Paolo Fabbri e Isabella Pezzini, que apresenta dez artigos e um tautograma que tratam do tema Pinóquio, alternando entre elementos do texto original, elementos presentes em variações do romance e abordagens sobre a tradução ou a variação em si, sob a óptica da semiótica discursiva. A perseverança e forte proliferação do tema Pinóquio, originalmente ou sob outros pontos de vista trazidos pelos meios de comunicação, estabelece o texto como uma fábula da atualidade que sempre atraiu o olhar científico.

Palavras-chave: variação; tradução intersemiótica; semiótica discursiva.

Abstract: Semiotic readings of Pinocchio - This review offers a brief commentary on the contents of Pinocchio: nuove avventure tra segni e linguaggi, organized by Paolo Fabbri and Isabella Pezzini. It presents ten essays and a tautogram that deal with the theme of Pinocchio, alternating between elements of the original text, elements present in variations of the novel, and approaches about the translation or variation itself, from the standpoint of discursive semiotics. The perseverance and strong proliferation of the Pinocchio theme, originally or from other points of view put forward by the mass media, establishes the text as a fable that is still relevant today and that has always attracted the scientific eye.

Keywords: variation; intersemiotic translation; discursive semiotics. 
Desde a primeira publicação de Le avventure di Pinocchio, escrito por Carlo Collodi em 1883, seguiram-se incontáveis publicações do romance, tornando-o possivelmente uma das obras italianas mais propagadas no mundo. Essa popularidade não se limitou à obra original, abrangendo também as diversas versões e reescrituras da narrativa. A partir dessa enorme proliferação, também tornou-se frequente a tomada do romance como objeto de estudos críticos e científicos. À obra Pinóquio: novas aventuras entre signos e linguagens ${ }^{1}$ coube o estudo do romance e de seu sucesso sob o viés semiótico. Publicado em 2012, o livro traz uma reunião de artigos científicos de pesquisadores italianos que abordam direta ou indiretamente o tema de Pinóquio.

O livro é composto por dez artigos que tratam de temáticas variadas, pertencentes à narrativa original de Pinóquio ou trazidas por novas versões, inclusive teatrais e cinematográficas. Dentre estas temáticas se destacam a variação e a tradução intersemiótica, em que se vê a maleabilidade cultural que a narrativa exibe, ao ser transcrita em inúmeros contextos diferentes. Vários outros temas da narrativa são abordados, como a espacialidade, as imagens e a análise semi-simbólica, assim como elementos emblemáticos como a baleia e as metamorfoses. O livro apresenta grande importância teórica para o estudo de variações e traduções, bem como para observação semiótica de mitos e narrativas.

O primeiro artigo, de Isabella Pezzini, intitulado Tra un Pinocchio e I'altro assume o objetivo de encontrar as raízes textuais do sucesso e da proliferação do texto de Pinóquio, e de iluminar alguns princípios de observação do corpus. O texto traça o fio das pesquisas realizadas até então. Há uma análise da temporalidade estabelecida entre o texto escrito e o visual, sobre as imagens presentes na primeira publicação do livro em um jornal. O artigo desenvolve questionamentos semióticos a partir de textos críticos sobre Pinóquio, incluindo aqueles trazidos pela própria obra.

Daniele Barbieri examina uma edição de Pinóquio de 1991, ilustrada por Lorenzo Mattoti. Aborda especificamente as próprias ilustrações, seguindo a linha de análise semiótica de imagens do autor. No caso de Pinóquio, a relevância das ilustrações remete às primeiras edições, visto que sempre acompanharam o romance; a tarefa de ilustrar Pinóquio configurou-se como um legado importante para os desenhistas que a assumiram. Entretanto, conforme estipula Barbieri, em Pinóquio as ilustrações são como parasitas do texto escrito, pois sua própria existência depende do primeiro, e o oposto não ocorre. $\mathrm{O}$ artigo analisa a expectativa produzida pela imagem que existe em função de um texto escrito; e como funciona a espera do leitor pelo que deve ocorrer na narrativa. Também é observado o efeito de sentido produzido pelo uso de materiais específicos. No caso das ilustrações de Mattoti estes efeitos criam paradoxos, como a exibição de uma imagem luminosa ao mesmo tempo diáfana e pastosa, que age sobre o leitor assumindo o papel de um personagem da narrativa.

1 Tradução livre, do original Pinocchio: nuove avventure tra segni e linguaggi. 
No artigo seguinte há uma análise sobre o modelo espacial em Pinóquio. Laura Barcellona expõe um esquema que mostra as oposições existentes entre os espaços casa vs estrada, homologados como espaço do destinador vs espaço do antidestinador. Assim é criada uma referenciação entre atores e espacialidades, na parte inicial do texto de Pinóquio; sendo que quando esta é posta em relação, na parte final do texto, faz emergir um modelo temporal que abrange os espaços de culpa ( $1^{\mathrm{a}}$ parte) e contrapasso ( $2^{\mathrm{a}}$ parte).

De Berti analisa a primeira versão cinematográfica de Pinóquio, de 1911. O artigo busca relacionar o texto original e o cinematográfico ao contexto comunicativo em que os filmes se inserem. Elementos característicos deste contexto incluem uma passagem de Pinóquio pela América do velho-oeste, inspirada pelo espetáculo de Buffalo Bill. Mantendo como objeto traduções em filmes, o texto de Nicola Dusi é focado sobre o personagem baleia, mostrando seu histórico na literatura mundial, e seu efeito de sentido no Pinóquio original e em algumas traduções fílmicas. O autor focaliza na sequência em que Pinóquio é engolido pela baleia, e observa as variações encontradas em novas versões do cinema.

Gradellini realiza um estudo sobre a roupa e os acessórios de Pinóquio nas versões teatrais. Estes elementos são caracterizados como identificadores e marcadores de transformações. Também são analisados os diversos tipos de Pinóquios elaborados pelas várias versões do texto, como o Pinóquio fêmea e os Pinóquios múltiplos. Por fim é feita uma associação do espírito de Pinóquio com a espécie humana e a atração pela aventura.

Em La natura di un burattino há uma apreciação sobre os mecanismos semióticos que articulam e estabelecem relações entre o plano da expressão e o plano do conteúdo. A partir desses planos o autor traz uma análise de tipo semi-simbólico, que não descreve os tipos mínimos do plano da expressão (gráfica ou fonética), e se mantém sobre a organização sêmica das figuras "armadilha" e "colar", conforme aparecem em trechos da obra Pinóquio. Assim, Lancioni descreve o plano do conteúdo sem passar pelo plano da expressão, não abordando elementos singulares do texto, mas apenas suas categorias. Segundo o autor, esta forma de análise é capaz de delinear a organização poética de praticamente qualquer texto.

No texto de Marrone há discussões sobre paralelismo e traduções intersemióticas, e relações entre interpretação e tradução. A partir de uma obra paralela à de Pinóquio (Pinocchio, un libro paralelo, de G. Manganelli), Marrone expõe o processo de somar um texto próprio ao texto matriz como uma forma de tradução, em que o texto matriz é enriquecido com novas expressões. Já o artigo sequencial se mantém na análise de traduções, expondo uma versão nigeriana de Pinóquio que cria uma nova narrativa, associando o protagonista a uma entidade mitológica nigeriana, o Ajantala. Por meio disso tem-se a adaptação do texto junto a elementos culturais próprios.

Por fim, no último texto, Fabbri discute os tipos de articulações a partir de Pinóquio, como hipótese as invariantes e variáveis, bem como os tipos de variáveis. O autor toma como hipótese para o sucesso de Pinóquio a emersão de um "mitismo" a partir do romance. 
Exemplificando, Fabbri aborda como alguns textos alteraram o que se julgava invariante sem mudar o sentido geral do texto, por meio da manutenção de alguma isotopia do texto original. O livro traz ainda um tautograma assinado por Umberto Eco, que apresenta uma forma de tradução minimalista e irreverente da narrativa de Pinóquio.

Rafael Giardini Lenzi é doutorando em Comunicação e Semiótica na PUC-SP com bolsa de estudos Fapesp; é pesquisador do Centro de Pesquisas Sociossemióticas, na PUC-SP.

lenzirafael@yahoo.com.br 